\title{
Oil Price Fluctuations and the Future of Saudi Arabian Non-Oil Traded Sector: An Empirical
} Investigation

\author{
Abdulaziz Hamad Algaeed \\ College of Business Administration, Dar Al Uloom University, Riyadh, Saudi Arabia \\ ibngaeed@outlook.com
}

\begin{abstract}
The major focus of this paper is to investigate theoretically and empirically the effects of non-linear oil price changes on Saudi manufacturing (traded) sector covering the period of 1970 till 2015, utilizing structural vector autoregressive (SVAR) approach. The Dutch disease syndrome will be clarified, and the impacts of oil price variations (increase and decrease) are investigated. Johansen's testing procedure result asserts the existence of stable long-run relationship between real traded sector (MANUFACTURING), oil price increase and decrease, real government expenditure (GOEX), real exchange rate (REX), and the mining sector (MINING). The findings confirm that OIL ${ }^{\text {shock }(+)}$, and REX influence MANU negatively, while the spending effect, GOEX affects MANU positively. However, this could be attributed to the government efforts to nullify the Dutch disease symptoms. Given, the obtained tests' results, the exchange rate REX appreciation confirms the existence of the Dutch disease, and consistent with the Dutch disease literature and findings. The Manufacturing sector harmed enough to the degree that government has to subsidize.
\end{abstract}

Keywords: Dutch Disease, Saudi Arabia, A non-linear oil price shocks, and SVAR

\section{Introduction}

During the last five decades, the kingdom of Saudi Arabia has gone through significant structural changes in response to the oil windfalls generated by the rise in oil prices in 1973/74, 1981/82, 2001/02, and 2009. Hagen (1968) described the typical oil economy as consisting of five parts: the font, the farm, the market, the bank, and the rest of the world. The productivity is high in the font. Government takes its foreign exchange earnings to the bank to convert it to local currency. The money will be spent in the low productive sector, the market. The spending can be either by the people or the government. The farm is the lowe productive part of the economy. In the market, the productive factors will earn income, which will be exchanged at the bank in order to get foreign exchange to finance their purchases from abroad. This description can be applied to all dependent economies. Nevertheless, the trouble comes from single commodity dependent economy such as oil, coffee, remittances, etc.

The oil boom had great effects on domestic expenditure. The predicted consequences are as follows: first, relative prices go up causing the exchange rate to appreciate since the small open economy is a price taker in the world market. The domestic price level is determined according to the supply and demand conditions. The oil boom has resulted in an increase in the price of non-traded goods relative to the traded goods. Among the factors that contributed to this change are the growth of money supply, government expenditure, and the change in the price of international goods. Second, the high exchange rate leads to a lowering of the country's competitiveness in the world market. The domestic price of the traded goods is the world's price of traded goods adjusted for the exchange rate. The variations in the exchange rate will have an effect on price of nontraded goods $\left(\mathrm{P}^{\mathrm{N}}\right)$ and the price of traded goods $\left(\mathrm{P}^{\mathrm{T}}\right)$ and hence, on the resource movements between traded and non-traded sectors. However, after the collapse of fixed exchange rate regime in 1971, Saudi Arabia pegged its currency (Riyal) to the US dollar. One of the main reasons for this policy is that, oil revenues are denominated in dollars, and the government hope for stable imports' prices. Thirdly, the production structure is shifted in favor of non-traded goods which affect the source of the foreign exchange. On the other hand, looking at the components of the Saudi GDP, one finds it difficult to separate the traded from non-traded sectors. Agriculture and manufacturing are labeled as traded sectors and services as non-traded sector. If we have an increase in relative price $\left(\mathrm{P}^{\mathrm{N}} / \mathrm{P}^{\mathrm{T}}\right)$, this means a fall in real wage causing an increase in the demand for labor in the non-traded sector. A rise in the relative price is equivalent to the rise in the price of non-traded goods. Decomposing the non-oil GDP into four major sectors yields a clear picture of the consequences of the Dutch disease. 
Moreover, recent studies concentrated on different causes of the Dutch disease. The rise in coffee prices in the late 1970s in Colombia brought a boom in the coffee sector at the expense of manufacturing and resources were reallocated to the agricultural sector. Other causes are studied extensively, Taguchi and Lama (2016); Eromenko (2016), and Acosta et al. (2007) on immigrant's remittances and their relation with Dutch disease, Fielding and Gibson (2012); Lar, Taguchi and Sakurai (2016); Magud and Sosa (2010) on foreign aid, and Javaid (2011) on the foreign currency inflows and their impacts on sectors of the economy. Paldam (2013), asserts that in the neo-classical model of Dutch disease, resources are considered a booming sector. However, resource sector is small enclave that produces resource rent. The rent is considered as a tax paid by the rest of the world and hence, resource sector generates inflow of foreign exchange. The influx of resource decreases labor supply. Moreover, resources rent force government to spend it all over the country. Since the booming sector is enclave, most of the value added is not produced but a resource rent (Paldam, 2013). As a matter of fact, economists looked at financial aspects of the Dutch disease where foreign direct investment flows towards the booming sector (Botta, 2014). This process causes exchange rate to appreciate. In addition, short term capital worsen exchange rate adding more pressure on exchange rate. As can be seen, in the longrun macroeconomic instability and the reliance on mineral exports suppress the traditional tradable good sectors and restrain productivity.

Equally important, it should be indicated that the benefits from oil abundance and oil price increase has shaped and structured the Saudi economy. In fact, the benefits of oil revenues flourished through major sectors of the economy and participated in the building the economy from a somewhat primitive to a well stand economy, and considered among other emerging economies. The changes in relative prices $\left(\mathrm{P}^{\mathrm{N}} / \mathrm{P}^{\mathrm{T}}\right)$ induce a reallocation of production factors from traded sectors in favor of non-traded sectors (resource movement effects). The increase in non-traded goods (spending effects) causes an appreciation of the exchange rate. The relative price and the spending effects (proxied by real government spending) have benefited the service sector in Saudi Arabia. Although there is no consensus among economists on a definite empirical evidence of a resource curse, the evidence is somewhat mixed. The association between resource abundance and economic growth are not conclusive. Some economists found a positive relationship; while others found it negative (Trevino, 2011). Hence, the existing evidence of the Dutch disease is a matter of empirical investigation case-by-case, to reach final and definite conclusions.

The main focus of this paper is to explore the impacts of recent fluctuations in oil prices on the non-traded, specifically the manufacturing sector in an emerging oil-based economy. Since the agricultural sector is small and weak, the reliance of the Saudi government is on the manufacturing sector in order to achieve the 2030 vision that is, diversification of the production base. It is clear that any oil price shocks (from the point of view of an oil-exporting country), will influence the earnings of oil and thereby spending and resource movement effects. This study differs from other studies in the following. First, SVAR methodology is applied. Secondly, this analysis is directed towards the real manufacturing sector, where the task is to see how oil prices volatility are channeled via REX, GOEX, and MINING, causing variations in this sector. Third, is to show empirically that the Saudi economy is undergone symptoms of Dutch disease. On the other hand, Figure 1shows the behavior of the determinants under study. MANU, GOEX, and MINING move in the same direction. The rise in oil revenues raises GOEX then MANU. By the same token, REX moves in line with the oil mining and GOEX. Relative price is likely to conform to the GOEX. The aim of this paper is to analyze and investigate empirically the existence of symptoms of the Dutch disease. To do so, the manufacturing traded sector is examined. Utilizing structural VAR (SVAR) technique, the effects of changes in oil prices REX, GOEX, and MINING on MANU are empirically and rigorously tested. This paper is organized as follows. Section 1 contains an introduction. Section 2 reviews existing theoretical and empirical related literature. Section 3 builds on the related theoretical model, estimation and discussions of the empirical findings, and section 4 consists of the conclusion and policy implications. 
Figure 1: Oil price, government expenditure, real exchange rate, mining, and manufacturing sectors

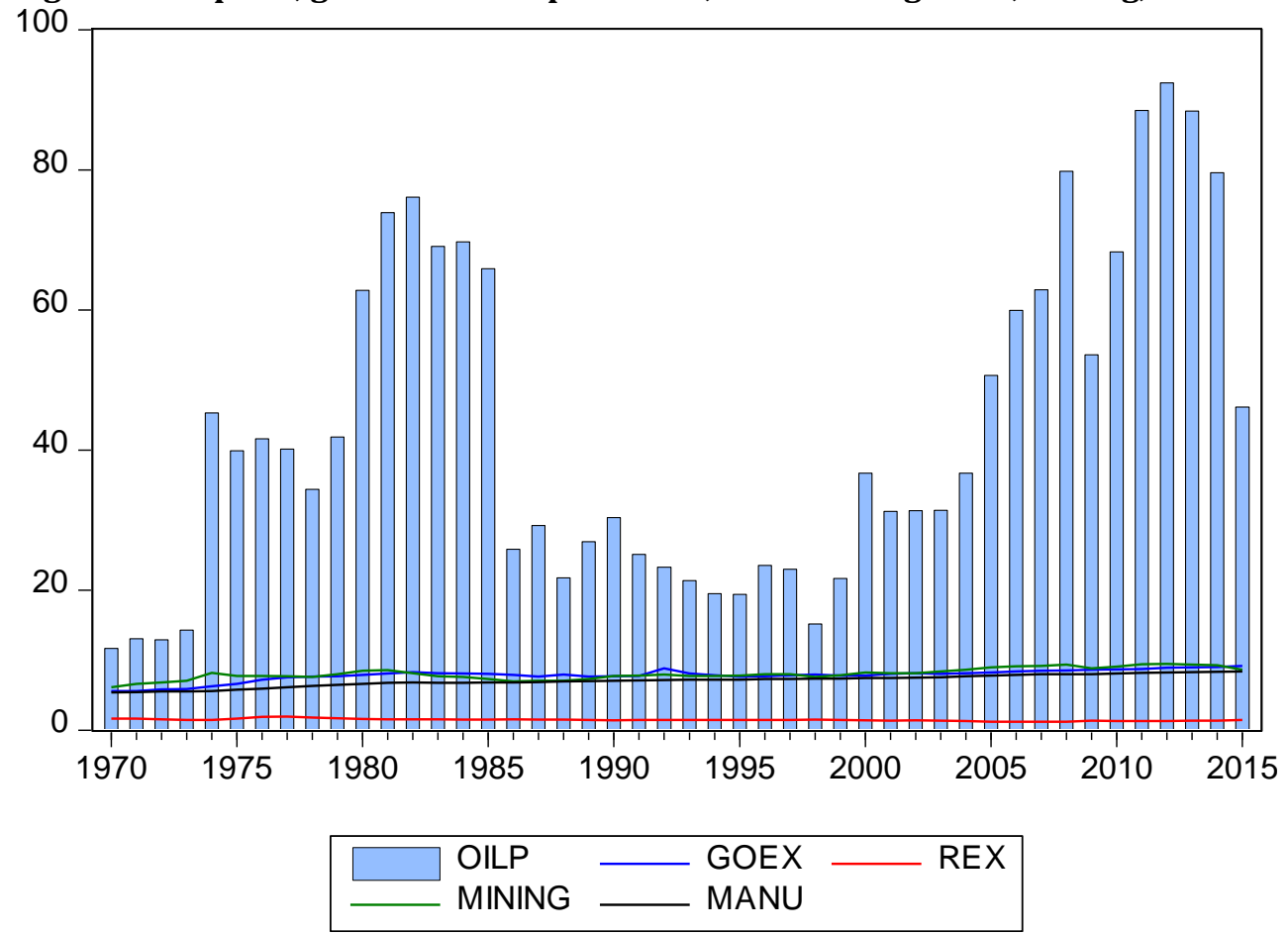

\section{Literature Review}

The recent growth of the mining industry oil, coal, etc. has led many economists to study the impacts of such booms on the rest of the home economy. Most theoretical analyses seem to agree that the price of non-mining traded goods will go up relative to traded good prices, and hence, the output of non-mining traded goods will shrink (Long, 1983). Equally important, the exploitation of mineral discoveries through exports would have an impact on the balance of payments of the lucky countries. In essence, natural gas discovery in Netherland influenced the exchange rate and relative prices causing the guilder to go up. Zuzana (2016) summarized the Dutch disease analysis with a small open economy which is consisted of three sectors. The two tradable good export sectors where prices are determined abroad and non-tradable goods is determined by local supply and demand, namely service sector. The sector that exports natural resources is called booming sector, which are the manufacturing and agricultural sectors. The major assumption is that capital is not mobile while labor is mobile between the three sectors. The goods are for final consumption, trade is balanced and commodity and factor prices are not distorted. The inflows of foreign currency from the booming sector cause higher demand, and spending effect occurs. The rise in demand for goods affects domestic prices or nominal exchange rate. Under fixed exchange rate, the inflows of foreign earnings increase money supply and hence, domestic prices. The flexibility of exchange rate will cause appreciation of the local currency leading to the rise in nominal exchange rate. Under fixed and flexible exchange rates, appreciation will occur. This situation reduces the competitiveness of the traditional good sectors and decreases exports. Imports become cheaper than local products causing labor and production to move from lagging traditional good sectors towards the non-traded good sectors. This is called de-industrialization. However, labor and production is in favor of nontraded sector, which called indirect de-industrialization or resource movement effect. Gregory (1976) developed a simple partial equilibrium model to analyze the impact of mineral development on the Australian economy. According to Snape (1977), the structure of Gregory's model was as follows: The discovery of minerals will lead to an increase in export supply which will bring external surplus. In order to correct this situation, revaluation or inflation would raise the non-traded good price relative to export and import prices. As a result of this, import-competing and pre-existing export industries are squeezed.

Porter (1978) concluded that the major lesson in terms of traded/ non-traded goods model is that, the gradual expansion of production possibility frontier to the right should have been associated with gradual 
revaluation of the currency. Failure to do so, inflation is inevitable. According to him, if the exchange rate is allowed to gradually float, the relative size of the manufacturing would gradually decline. However, a rigid exchange rate policy would contribute to external imbalance. Neary and Corden (1982) were concerned with the phenomena called the Dutch disease. Their aim is to explore the nature of the resulting pressure toward de-industrialization. Their work is an extension of the work done by Snape (1977). Their primary work involves the effects of asymmetric growth on resource allocation and income distribution. They concluded that both the resource and the spending effects have contributed to the fall in the manufacturing sector with some reservations. Enders and Herberg (1982) developed a model to explain the Dutch disease. They assumed a fixed exchange rate. They concluded that the resource boom would lead to a decline in production and employment in the traditional export sectors (agriculture and manufacturing). The spending effect would increase the price of services leading to a higher nominal wage in both the service and the resource sectors. They suggested a cure for the Dutch disease such as price policy and production subsidy. Given these points, Corden (1984) surveyed the Dutch disease literature and developed an analytical model to explain the resource movement impact and spending effect. In the first paper, he tried to analyze the effect of monetary policy contraction and the oil boom in the United Kingdom. Using static analysis diagrams, he concluded that a monetary squeeze damage both the traded and non-traded good sectors. The similar effect from North Sea oil tends to squeeze the traded sector in the short-run. However, in the medium run, when adjustment takes place, there will be a shift from tradable to non-tradable goods. He asserted that this mechanism depends on the fiscal policy concerning oil revenues.

Wijnbergen (1984 a, b), presented an equilibrium model which is founded on Meade-Salter-Swan model of an open economy. The economy produces two goods: traded and non-traded. He assumed neoclassical production function where capital is not mobile and fixed. He argues that higher transfers (due to an increase in oil prices) lead to excess demand for non-traded goods. As a result of this development, real appreciation must take place causing resources to move out of the traded sector into the non-traded sector (service). Thus, he extended his model to deal with employment effects and inflation. Neary and Wijnbergen (1984), built on Eastwood and Venables model and incorporated wealth effect. However, their argument is this: with a strictly positive wealth elasticity of money demand, higher wealth leads to an incipient excess demand for money after an oil discovery. To accommodate this increase, the real money stock has to rise. They concluded that the rise in the money demand given the nominal money supply may cause contraction which will be sufficient to offset the expansionary effect of the oil boom. Hence, monetary policy can resolve this problem. Kamas (1986), developed macro econometric model incorporating the exchange rate and relative prices to see whether or not the Dutch disease exists in Colombian economy. Her theoretical justification is built on Corden and Neary (1982), and Corden (1986). Her macro models are examined at two levels. First, is to see the effect of coffee's boom on relative price and exchange rate. Secondly, is to see the effects of exchange rate and relative price over the aggregated sectors of the economy. Proxies are used for traded and non-traded prices. She concluded that during the period of 1967-1982, the Colombian economy experienced the Dutch disease and its consequences. Nevertheless, this study is mainly an application of Dutch disease literature.

Fardmanesh (1991), developed a three sector reduced form model to test the existence of the Dutch disease in five oil producing countries, Algeria, Ecuador, Indonesia, Nigeria and Venezuela. He used the world price and the shares of agriculture, manufacturing and service sectors in the non-oil GDP. He concluded that oil boom has affected the composition of agricultural sector in favor of the service and manufacturing sectors. This interesting study can be criticized on grounds that the spending effect is not accounted for. Moreover, the home price should be used to visualize the effects of the oil boom and the home price on the traded and non-traded sectors. Mironov and Petronevich (2015) examine the presence of the Dutch disease in Russian economy based on the classical model of the Dutch disease developed by Corden and Neary (1982). They analyze the correlations between changes in the real effective exchange rate of Ruble and the structural changes of the Russian economy for the period of 2002-2013. They estimated the resource movement and the spending effects and found signs of the Dutch disease. One of the signs is the negative impact of the effective exchange rate on the manufacturing sector economic growth, and on the workers' income changes. They also found positive link between effective exchange rate and returns on capital in the three sectors. However, the shift of labor from the manufacturing sector to the service sector cannot be explained by the Ruble appreciation alone. There are other factors affecting it. In the final analysis, recent literature is full of 
empirical studies that have been dealt with some aspects of the Dutch disease such as foreign remittances inflow and foreign aids.

\section{Methodology and Results}

Following Botta (2014), macroeconomic framework of the financial Dutch disease, the long-term foreign direct investment (FDI) and short-term portfolio investment are allowed. The FDI concentrates on domestic natural resources sector only. Portfolio investment is in the form of short-term/medium term foreign debt. The model consists of two non-linear differential equations. Equation (1), determines exchange rate dynamics such that:

$\dot{e}=e\left\{\left[\operatorname{imp}_{\mathrm{M}}(\mathrm{e})-\exp _{\mathrm{M}}(\mathrm{e}) / \mathrm{e}\right]-\exp _{\mathrm{NR}}+\mathrm{i}_{\mathrm{H}} \mathrm{D}+\Phi_{\mathrm{NR}}+\dot{R}+\mathrm{KA}_{\mathrm{PI}}\left(\mathrm{i}_{\mathrm{H}}-\mathrm{i}_{\mathrm{F}}-\delta(\mathrm{e}, \mathrm{D})\right)-\mathrm{KA}_{\mathrm{FDI}}(\mathrm{N})\right\}$

The imports and exports flows of manufacture goods are in foreign currency. Foreign currency denominated exports of domestic natural resources $\exp _{\mathrm{NR}}$, like oil. $\mathrm{i}_{\mathrm{H}} \mathrm{D}$ is interest payments on foreign debt. $\Phi_{\mathrm{NR}}$ is foreign firms profit and natural resources revenues. Foreign revenue variation is in the central bank $\dot{R}$; net capital inflow $\mathrm{KA}_{\mathrm{PI}}$; and $\mathrm{KA}_{\mathrm{FDI}}$. Furthermore, manufactured goods imports are in the foreign currency, and exports are in domestic currency. Both goods respond negatively and positively to nominal exchange rate respectively. It is interesting to note that manufactured goods, exports and non-traditional traded goods sectors are affected by real exchange rate. Although the inclusion of relative price in this model is viable, the decision is to ignore it since the model would not be affected. Finally, the amount of capital inflow is determined by the difference between $\left(\mathrm{i}_{\mathrm{H}}-\mathrm{i}_{\mathrm{F}}\right)$, where $\mathrm{i}_{\mathrm{H}}$ and $\mathrm{i}_{\mathrm{F}}$ are domestic and foreign investment risk $\delta$. It is worthwhile to note that as exchange rate appreciates, the more domestic borrowers meet their payments in foreign currency. Hence, there exists negative relationship between domestic exchange rate and short-term portfolio capital inflows. $\mathrm{KA}_{\mathrm{FDI}}$ is not assumed to depend on exchange rate because it is directed towards natural resources which exported to foreign markets. Thus, it is influenced positively by the stock of natural resources N. R is used by central bank to affect exchange rate in line with inflation target. Net portfolio flows consists of financial loans as a foreign debt changes as:

$\dot{D}=\mathrm{KA} A_{\mathrm{PI}}\left(\mathrm{i}_{\mathrm{H}}-\mathrm{i}_{\mathrm{F}}-\delta(\mathrm{e}, \mathrm{D})\right)$

Where:

$\partial \mathrm{KA}$ PI $\partial \delta<0 ; \quad \partial \delta / \partial \mathrm{e}>0 ; \quad \partial \delta / \partial \mathrm{D}>0$.

The higher current foreign debt, the less domestic borrower loans get. To derive equation (1) with respect to the current exchange rate, the form can be reached after some manipulation process as:

$\partial \dot{e} / \partial \mathrm{e} \mid \dot{e}_{=0}=\exp _{\mathrm{M}} / \mathrm{e}\left\{\gamma_{\mathrm{impM}}^{\mathrm{e} X}-\gamma_{\mathrm{expM}}+1\right\}-\mathrm{e} \partial \mathrm{K} A_{\mathrm{PI}} / \partial \delta \cdot \partial \delta / \partial \mathrm{e}$

Where:

$\mathrm{X}=\mathrm{imp}_{\mathrm{M}} /\left(\exp _{\mathrm{M}} / \mathrm{e}\right)$, the manufacture import-export ratio.

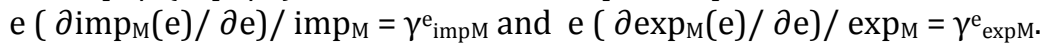

The manufactured goods imports and exports are elastic to exchange rate. The first part is Marshall-Learner condition represents the initial manufacturing trade imbalance. With capital mobility, exchange rate dynamics depends on trade flows among other factors. The second part of equation (3) shows the effects of exchange rate shift on net capital flows. The signs could be either positive or negative. Negative is in the case of future depreciation of the home currency. Nonetheless, the higher is the foreign debt, the more appreciation of the exchange rate. The connection between $\mathrm{D}$ and $\dot{e}$ is satisfied as follows:

$\partial \dot{e} / \partial \mathrm{D} \mid \dot{e}_{=0}=\mathrm{ei}_{\mathrm{H}}-\mathrm{e} \partial \mathrm{W} A_{\mathrm{PI}} / \partial \delta \cdot \partial \delta / \partial \mathrm{D}>0$

The goal of a resource abundant country is to enlarge the manufacturing sector. Its aim is possible to reach upper levels since it is full of opportunities to innovate and produce more in comparison with other sectors of the economy. The development of manufacturing sector can promote growth and considered a positive structural move. To look at factors that affect manufacturing progress with the assumption of manufacturing development through its share in real GDP (Botta, 2014).

$\mathrm{MA}=\mathrm{f}\left(\mathrm{e}, \rho, \mathrm{WA}_{\mathrm{PI}}, \mathrm{K}_{\mathrm{NR}}\right)$

$\partial \mathrm{MA} / \partial \mathrm{e}>0 ; \quad \partial \mathrm{MA} / \partial \mathrm{WA}_{\mathrm{PI}}<0 ; \quad \partial \mathrm{MA} / \partial \mathrm{K}_{\mathrm{NR}}<0$

Equation (5) is based on the assumption that non resource-based tradable good sectors, as a share of GDP, are positively affected by depreciated exchange rate. As a result, manufacturing development responds positively to the depreciation of the exchange rate. $\rho$ represents the exchange rate variance. It may go up due 
to interaction between FDI, short-term portfolio investment and exchange rate movements. Hence, as $\rho$ rises, manufacturing sector declines. Furthermore, manufacturing development may be affected negatively by net portfolio capital inflows even there is no empirical evidence for this conclusion. Manufacturing development is affected negatively by the investment in natural resources sector. Looking at equation (6), there exist positive relationship between productivity $\mathrm{Y}_{\mathrm{L}}$ growth and manufacturing sector development as:

$\mathrm{Y}_{\mathrm{L}}=\mathrm{g}(\mathrm{MA})$

Where:

$\partial \mathrm{Y}_{\mathrm{L}} / \partial \mathrm{MA}>0 ; \partial\left(\partial \mathrm{Y}_{\mathrm{L}} / \partial \mathrm{MA}\right) / \partial \mathrm{MA}<0$;

In sum, the natural resource sector will attract FDI, where capital stock will motivate natural resource exports and hence, manufacturing sector will decline and non-traded good sector (service sector) will expand. Since our attention here is concentrated on the real log traded (manufacturing) sector, the following eclectic model is specified:

MANU $_{\mathrm{t}}=\mathrm{f}\left(\mathrm{OILPI} ; \mathrm{REX}_{\mathrm{t}} ; \mathrm{GOEX}_{\mathrm{t}} ;\right.$ MINING $\left._{\mathrm{t}}\right)$

$\mathrm{f}_{1}$, and $\mathrm{f}_{2}<0 ; \mathrm{f}_{3}$, and $\mathrm{f}_{4}>0$

MANU $_{\mathrm{t}}=\mathrm{f}\left(\mathrm{OILPD}_{\mathrm{t}} ; \mathrm{REX}_{\mathrm{t}} ; \mathrm{GOEX}_{\mathrm{t}} ; \mathrm{MINING}_{\mathrm{t}}\right)$

$\mathrm{f}_{1}$, andf $\mathrm{f}_{2}<0 ; \mathrm{f}_{3}$, and $\mathrm{f}_{4}>0$

Where:

$\mathrm{MANU}_{\mathrm{t}}$ is real log manufacturing sector. It includes: food, beverages and tobacco, textiles, wood, petroleum, coal and chemicals. It is calculated as follows: MANU = GDP (minus import duties) - (service + mining).

OILP ${ }_{t}^{i}$ is change in real oil price; $\mathrm{i}=\mathrm{I}$ (increase), and $\mathrm{D}$ (decrease).

$\mathrm{REX}_{\mathrm{t}}$ is real exchange rate calculated as: Riyal (Saudi Currency)*CPI/WCPI.

$\mathrm{GOEX}_{\mathrm{t}}$ is real log government expenditure representing the spending effect.

MINING $_{\mathrm{t}}$ is real $\log$ value of mining sector.

The Non-Linear Oil Price Effects: Nowadays, in the prominent literature, the symmetric real oil prices shock is specified as follows:

$\Delta \mathrm{OILP}_{\mathrm{t}}=\mathrm{OILP}_{\mathrm{t}}-\mathrm{OILP}_{\mathrm{t}-1}$

Where asymmetric real oil price shocks (positive OILPI $\mathrm{I}_{\mathrm{t}}$ and negative $\mathrm{OILPD}_{\mathrm{t}}$ ) are constructed as:

OILPI $=\max \left\{0, \Delta \mathrm{OILP}_{\mathrm{t}}\right\}$

$\operatorname{OILPD}_{\mathrm{t}}=\min \left\{0, \Delta \mathrm{OILP}_{\mathrm{t}}\right\}$

The data used here, is collected from SAMA (Saudi Arabian Monetary Authority), annual statistics 2016. The real oil price implemented here is an OPEC basket price. The data covers the period of 1970-2015. Table 1 shows estimates of Ordinary Least Squares (OLS). The impact of oil price increase on MANU is negative as expected, and not significant, and between $0.15-0.22$ percent. The effect of oil price decrease is negative, as expected a priori, but is not significant, and in the same range of the oil price increase, that is $0.15-0.27$ percent. On the whole, the magnitude of variations of the oil prices is negligible. The sign of REX is negative indicating that 206 to 213 percent of the variations in MANU come from the variation in real exchange rate (appreciation of REX) Javaid (2011), Mironov and Petronevich (2015), Taguchi and Lama (2016), and Lar et al. (2016). By the same token, the effect of GOEX on the MANU is positive and significant at 1 percent level. The positive sign indicates that the Saudi government is working hard to support the manufacturing sector in order to boost the production base. After all, the model is free of serial correlation and stable too.

Unit Root Test: The AR (1) process is as follows:

$\mathrm{y}_{\mathrm{t}}=\delta \mathrm{y}_{\mathrm{t}-1}+\varepsilon_{\mathrm{t}}$

$\varepsilon t \sim \operatorname{iid} N\left(0, \sigma^{2}\right)$

Here, the purpose is to test whether $\delta$ is equal to 1 or not. When we subtract $\mathrm{y}_{\mathrm{t}-1}$ from both sides, the AR (1) can be rewritten as:

$\Delta \mathrm{y}_{\mathrm{t}}=\mathrm{y}_{\mathrm{t}}-\mathrm{y}_{\mathrm{t}-1}=(\delta-1) \mathrm{y}_{\mathrm{t}-1}+\varepsilon_{\mathrm{t}}$

Performing a test for $\delta=1$ is an easy task through t-test to check whether the parameter on the $\mathrm{y}_{\mathrm{t}-1}$ is equal to zero or not. This is the Dickey-Fuller test. Furthermore, performing unit root tests is the goal to attain stationary variables, and avoid spurious in multivariate regressions. To go on in the analysis, Augmented Dickey-Fuller (ADF), and Phillips and Perron (PP) tests are applied. Results for these tests are close to each other, and thus, reported in table 2 . The tests revealed that all variables are stationary at the 
difference I(1) and significant at 1 and 5 percent level in the ADF and PP tests. Some of the variables, such as MANU $_{\mathrm{t}}, \mathrm{REX}_{\mathrm{t}}, \mathrm{GOEX}_{\mathrm{t}}$ and the MINING $\mathrm{t}$ variables, are not stationary at level I(0).

Table 1: Dependent variable real manufacturing sector (MANU)

\begin{tabular}{|c|c|c|c|c|c|c|c|c|}
\hline $\begin{array}{l}\text { Dependent } \\
\text { Variable }\end{array}$ & Intercept & OILPI & OILPD & REX & GOEX & MINING & $\mathbf{R}^{2}$ & F-statistic \\
\hline MANU-1 & $\begin{array}{l}4.864386 \\
(7.0871)^{*}\end{array}$ & $\begin{array}{l}-0.001512 \\
(-1.4264)\end{array}$ & & $\begin{array}{l}-2.132103 \\
(-8.4475)^{*}\end{array}$ & $\begin{array}{l}0.681721 \\
(13.2125)^{*}\end{array}$ & & 0.93 & 176.4733 \\
\hline MANU-2 & $\begin{array}{l}4.275716 \\
(5.4801)^{* *}\end{array}$ & $\begin{array}{l}-0.002200 \\
(-1.9318)\end{array}$ & & $\begin{array}{l}-1.978681 \\
(-7.3708)^{*}\end{array}$ & $\begin{array}{l}0.611963 \\
(8.9111)^{*}\end{array}$ & $\begin{array}{l}0.114400 \\
(1.5092)\end{array}$ & 0.93 & 137.1526 \\
\hline MANU-3 & $\begin{array}{l}4.596444 \\
(6.9210)^{*}\end{array}$ & & $\begin{array}{l}-0.001510 \\
(-0.5458)\end{array}$ & $\begin{array}{l}-2.061975 \\
(-8.1455)^{*}\end{array}$ & $\begin{array}{l}0.699124 \\
(13.7541)^{*}\end{array}$ & & 0.92 & 166.6105 \\
\hline MANU-4 & $\begin{array}{l}4.128436 \\
(5.1205)^{* *}\end{array}$ & & $\begin{array}{l}-0.002794 \\
(-0.9201)\end{array}$ & $\begin{array}{l}-1.943705 \\
(-6.9871)^{*}\end{array}$ & $\begin{array}{l}0.652192 \\
(9.5261)^{*}\end{array}$ & $\begin{array}{l}0.081174 \\
(1.0226)\end{array}$ & 0.93 & 125.3584 \\
\hline
\end{tabular}

$*^{*}, * *$, and ${ }^{* * *}$ are statistically significant at $1 \%, 5 \%$ and $10 \%$ level respectively. Values in parentheses are tvalues.

Table 2: Augmented-Dickey Fuller and Phillips-Perron tests

\begin{tabular}{|c|c|c|c|c|c|c|c|c|c|c|c|c|}
\hline \multirow[b]{3}{*}{ series } & \multirow{2}{*}{\multicolumn{6}{|c|}{ Augmented-Dickey Fuller }} & \multicolumn{6}{|c|}{ Phillips-Perron } \\
\hline & & & & & & $1^{\text {st }}$ Difference & \multicolumn{3}{|c|}{ Level } & \multicolumn{3}{|c|}{$1^{\text {st }}$ Difference } \\
\hline & Intercept & T\&I & None & Intercept & T\&I & None & Intercept & T\&I & None & Intercept & T\&I & None \\
\hline MANU $_{\mathrm{t}}$ & 1.73 & 2.65 & $2.25^{* *}$ & $3.49^{* *}$ & $3.67^{*}$ & $2.20^{* *}$ & 1.58 & 1.92 & $4.21^{*}$ & $3.49^{* *}$ & $3.67^{* *}$ & $2.20^{* *}$ \\
\hline OILPI $_{t}$ & $6.37^{*}$ & $6.44^{*}$ & $5.48^{*}$ & $9.88^{*}$ & $9.73^{*}$ & $10.14^{*}$ & $6.43^{*}$ & $6.53^{*}$ & $5.47^{*}$ & $32.44^{*}$ & $34.01^{*}$ & $33.52 *$ \\
\hline OILPD $_{t}$ & $6.69 *$ & $6.65^{*}$ & $5.08^{*}$ & $7.61^{*}$ & $7.52^{*}$ & $7.67^{*}$ & $6.69 *$ & $6.65^{*}$ & $5.42^{*}$ & $17.04^{*}$ & $16.76^{*}$ & $17.08^{*}$ \\
\hline $\mathrm{REX}_{\mathrm{t}}$ & 1.20 & 2.01 & 0.89 & $3.39 * *$ & $3.31^{* *}$ & $3.43^{*}$ & 1.59 & 2.33 & 1.18 & $3.09^{* *}$ & $3.10^{* *}$ & $3.14^{*}$ \\
\hline $\mathrm{GOEX}_{\mathrm{t}}$ & 2.26 & 2.47 & 1.79 & $6.88^{*}$ & $6.98^{*}$ & $6.33^{*}$ & 2.30 & 2.43 & 1.79 & $6.87^{*}$ & $6.98^{*}$ & $6.33^{*}$ \\
\hline MININGt & 2.14 & 2.55 & 0.91 & $5.63^{*}$ & $5.64^{*}$ & $5.62 *$ & 2.43 & 3.67 & 0.86 & $5.60^{*}$ & $5.62 *$ & $5.61^{*}$ \\
\hline
\end{tabular}

$*, * *$, and ${ }^{* * *}$ are statistically significant at $1 \%, 5 \%$ and $10 \%$ level respectively. T\&I: trend and intercept.

Johansen Co-integration Test Result: Based on Hjalmarsson and Osterhold (2007) in Algaeed (2017), Johansen's methodology starts with $\operatorname{VAR}(\mathrm{p})$ as:

$\mathrm{y}_{\mathrm{t}}=\Psi+\mathrm{A}_{1} \mathrm{Y}_{\mathrm{t}-1}+\ldots+\mathrm{A}_{\mathrm{p}} \mathrm{Y}_{\mathrm{t}-\mathrm{p}}+\mathrm{e}_{\mathrm{t}}$

Where: $y_{t}$ is a nx1 vector of variables that are integrated of order one. $\varepsilon_{t}$ is a $n \times 1$ vector of innovations. The VAR model can be written as follows:

$\Delta \mathrm{y}_{\mathrm{t}}=\Psi+\Pi \mathrm{y}_{\mathrm{t}-1}+\sum_{i=1}^{p-1} \Gamma_{\mathrm{i}} \Delta \mathrm{y}_{\mathrm{t}-\mathrm{i}}+\mathrm{e}_{\mathrm{t}}$

Where:

$\Pi=\sum_{i=1}^{p} A i-I$, and $\Gamma_{\mathrm{i}}=-\sum_{j=i+1}^{p} A j$

If the coefficients of matrix $\Pi$ has minimized rank $\mathrm{r}<\mathrm{n}$, then there exist $\mathrm{n} \times \mathrm{r}$ matrices $\varphi$ and $\Phi$ each with rank r such that: $\Pi=\varphi \Phi$ and $\Phi_{y_{\mathrm{t}}}$ is stationary. Moreover, the reduced rank of the $\Pi$ matrix is the trace and the maximum eigenvalue tests as:

$\mathrm{J}_{\text {Trace }}=-\mathrm{T} \sum_{i=r+1}^{n} \ln \left(1-\hat{\lambda}_{\mathrm{i}}\right)$

$\mathrm{J}_{\text {Max }}=-\mathrm{T} \ln \left(1-\hat{\lambda}_{\mathrm{r}+1}\right)$

The analysis here used 3 lags for both OILPD and OILPI depending on unrestricted VAR lag order, LR, FPE, AIC, and HQ. From table 3, trace statistic test confirms the existence of 2 and 1 co-integrated equations at the 5 percent level. The null hypotheses for the trace and max tests are that, there are no co-integrations between OILPI and OILPD, GOEX, REX, MINING, and MANU. The null hypotheses are rejected. Thus, there exist longrun relationships among the variables. 
Table 3: Johansen co-integration test

\begin{tabular}{lllllllll}
\hline $\mathbf{H}_{\mathbf{0}}$ & $\mathbf{H}_{\mathbf{A}}$ & Eigenvalues & $\boldsymbol{\lambda}_{\text {Trace }}$ & $\mathbf{9 5 \%}$ & $\mathbf{H}_{\mathbf{0}}$ & $\mathbf{H}_{\mathbf{A}}$ & $\boldsymbol{\lambda}_{\operatorname{Max}}$ & $\mathbf{9 5 \%}$ \\
\hline \multicolumn{2}{l}{ With OILPI (lags = 3) } & & & & & & & \\
$\mathrm{r}=0$ & $\mathrm{r}=1$ & 0.858839 & $152.9488^{*}$ & 69.81889 & $\mathrm{r}=0$ & $\mathrm{r}=1$ & $70.48284^{*}$ & 33.87687 \\
$\mathrm{r}=1$ & $\mathrm{r}=2$ & 0.787482 & $82.46597^{*}$ & 47.85613 & $\mathrm{r}=1$ & $\mathrm{r}=2$ & $55.75420^{*}$ & 27.58434 \\
$\mathrm{r} \leq 2$ & $\mathrm{r}=3$ & 0.369213 & 26.71177 & 29.79707 & $\mathrm{r} \leq 2$ & $\mathrm{r}=3$ & 16.58833 & 21.13162 \\
\multicolumn{2}{l}{ With OILPD (lags = 3) } & & & & & & & \\
$\mathrm{r}=0$ & $\mathrm{r}=1$ & 0.645458 & $82.49134^{*}$ & 69.81889 & $\mathrm{r}=0$ & $\mathrm{r}=1$ & $42.51404^{*}$ & 33.87687 \\
$\mathrm{r} \leq 1$ & $\mathrm{r}=2$ & 0.462759 & 39.97731 & 47.85613 & $\mathrm{r} \leq 1$ & $\mathrm{r}=2$ & 25.47364 & 27.58434 \\
$\mathrm{r} \leq 2$ & $\mathrm{r}=3$ & 0.166761 & 14.50366 & 29.79707 & $\mathrm{r} \leq 2$ & $\mathrm{r}=3$ & 7.479848 & 21.13162 \\
\hline
\end{tabular}

$\mathrm{r}$ indicates the number of co-integrating vector. Critical values are from Mackinnon et al. (1991) p-values. * indicates significance of the test statistic at $5 \%$ level.

Causality Tests: If there are two variables or two groups of variables $j$ and $k$, then the necessary and sufficient condition for variable $\mathrm{k}$ not Granger cause variable $\mathrm{j}$ is that $\mathrm{A}_{\mathrm{jk}, \mathrm{i}}=0$ for $\mathrm{i}=1,2, \ldots$., Tables 4 and 5 reveal the causality tests. Pairwise Grange causality tests showed that causality is running from MINING to GOEX and from MANU to REX. On the other hand, causality test indicates clearly the acceptance of the null hypotheses that MINING do not Granger cause GOEX, and MANU does not Granger on REX. In essence, the null hypotheses for MINING does not Granger on GOEX and MANU does not Granger on REX are clearly accepted.

Table 4: Pairwise Granger causality tests, lags 5

\begin{tabular}{llll}
\hline Null Hypothesis & Observations & F-statistic & Probability \\
\hline GOEX does not Granger cause OILPI & 34 & 1.44857 & 0.2449 \\
OILPI does not Granger cause GOEX & & 2.12242 & 0.0990 \\
REX does not Granger cause OILPI & 34 & 0.69014 & 0.6359 \\
OILPI does not Granger cause REX & & 1.72533 & 0.1688 \\
MINING does no Granger on OILPI & 34 & 0.35630 & 0.8773 \\
OILPI does no Granger on MINING & & 0.47941 & 0.7879 \\
MANU does not Granger on OILPI & 34 & 1.16558 & 0.3559 \\
OILPI does not Granger on MANU & & 0.27923 & 0.9197 \\
REX does not Granger on GOEX & 41 & 0.72436 & 0.6105 \\
GOEX does not Granger on REX & 41 & 1.82569 & 0.1379 \\
MINING does not Granger on GOEX & & 3.46507 & 0.0137 \\
GOEX does not Granger on MINING & 41 & 0.64270 & 0.6690 \\
MANU does not Granger on GOEX & & 3.11583 & 0.0221 \\
GOEX does not Granger on MANU & 41 & 2.16418 & 0.0848 \\
MINING does not Granger on REX & & 1.60503 & 0.1890 \\
REX does not Granger on MINING & 41 & 1.84639 & 0.1338 \\
MANU does not Granger on REX & & 2.57476 & 0.0472 \\
REX does not Granger on MANU & 41 & 2.32031 & 0.0678 \\
MANU does not Granger on MINING & & 1.63951 & 0.1800 \\
MINING does not Granger on MANU & & 0.79001 & 0.5652 \\
\hline
\end{tabular}

The Impulse Response Function: Granger-causality tests may not explain well the interaction between variables in a system contains different variables. In the real world, attention is paid to the response of one variable to an impulse in another variable in a system that contains different variables. If a variable reacts to an impulse in another variable, this will yield the latter causal for the former (Rossi, 2004), in Algaeed (2017). Following the literature, the Saudi economy can be represented by structural equations as follows:

$A(L) X_{t}+B(L) Y_{t}=U_{t}$

Where $A(L)$ and $B(L)$ are $n x m$, and $n x k$ matrices. $X_{t}$ is an $n x 1$ vector of exogenous variables and $Y_{t}$ is $k x 1$ vectors of endogenous variables. $U_{t}$ is an $n \times 1$ vector of random structural disturbances. The SVAR explains the effects of one standard deviation shock in the error term over the model's endogenous variables. The model applied here will have five variables with 5-dimentional column vector. 
Table 5: Pairwise Granger causality tests, lags 5

\begin{tabular}{llll}
\hline Null Hypothesis & Observations & F-statistic & Probability \\
\hline GOEX does not Granger cause OILPD & 40 & 0.37610 & 0.8609 \\
OILPD does not Granger cause GOEX & & 1.02166 & 0.4232 \\
REX does not Granger cause OILPD & 40 & 0.16946 & 0.9718 \\
OILPD does not Granger cause REX & & 0.43337 & 0.8215 \\
MINING does no Granger on OILPD & 40 & 1.19247 & 0.3372 \\
OILPD does no Granger on MINING & & 0.87698 & 0.5087 \\
MANU does not Granger on OILPD & 40 & 0.73778 & 0.6013 \\
OILPD does not Granger on MANU & & 0.94731 & 0.4657 \\
REX does not Granger on GOEX & 41 & 0.724436 & 0.6105 \\
GOEX does not Granger on REX & & 1.82569 & 0.1379 \\
MINING does not Granger on GOEX & 41 & 3.46507 & 0.0137 \\
GOEX does not Granger on MINING & & 0.64270 & 0.6690 \\
MANU does not Granger on GOEX & 41 & 3.11583 & 0.0221 \\
GOEX does not Granger on MANU & 41 & 2.16418 & 0.0848 \\
MINING does not Granger on REX & & 1.60503 & 0.1890 \\
REX does not Granger on MINING & 41 & 1.84639 & 0.1338 \\
MANU does not Granger on REX & & 2.57476 & 0.0472 \\
REX does not Granger on MANU & 41 & 2.32031 & 0.0678 \\
MANU does not Granger on MINING & & 1.63951 & 0.1800 \\
MINING does not Granger on MANU & & 0.79001 & 0.5652 \\
\hline
\end{tabular}

Where: $\mathrm{y}_{\mathrm{t}}=\left(\mathrm{OILP}, \mathrm{GOEX}_{\mathrm{t}}, \mathrm{REX}_{\mathrm{t}}\right.$, MINING $\left._{\mathrm{t}}, \mathrm{MANU}_{\mathrm{t}}\right)$ is a $5 \mathrm{x} 1$ vector of endogenous variables. A is a $5 \mathrm{x} 1$ vector of constant terms. $B_{i}$ is an $5 \times 5$ autoregressive coefficient matrices. $U_{t}$ is a $5 \times 1$ vector of serially mutual uncorrelated shocks. The $i^{\text {th }}$ is an oil price increase and decrease. The restrictions imposed and the contemporaneous structural parameter of the following order:

$\left[\begin{array}{c}\text { OILPi } \\ \text { GOEX } \\ \text { MINING } \\ \text { REX } \\ M A N U\end{array}\right]=\left[\begin{array}{ccccc}1 & 0 & 0 & 0 & 0 \\ a 21 & 1 & 0 & 0 & 0 \\ a 31 & a 32 & 1 & 0 & 0 \\ a 41 & a 42 & a 43 & 1 & 0 \\ a 51 & a 52 & a 53 & a 54 & 1\end{array}\right]\left[\begin{array}{c}e 1 t \\ e 2 t \\ e 3 t \\ e 4 t \\ e 5 t\end{array}\right] ; \mathrm{i}=$ increase $(+)$ and decrease $(-)$

As can be seen, equation (17) is built on the assumption that the oil price changes are exogenously determined, and of course, this is the case. In order to examine the interactions and consolidate the causal relationships, SVAR, and impulse response functions and variance decomposition functions are used. In other words, the impulse response function from a VAR is a guide to whether the effects are short lived or permanent (Algaeed, 2017). It traces the effects of a one standard deviation shock in a certain variable on the current and future values of the rest of macro variables. Figure 2, 3, and table 6 and 7 show the IRFs of each variable in the study to a one standard deviation shock in the oil price. The response of MANU to OILPI is negative and continues negative till after the $20^{\text {th }}$. At the beginning, the response of MANU to OILPI is positive and continues positively till the end of time span. The response of REX is negative until the $3^{\text {rd }}$ year, then becomes negative up to $9^{\text {th }}$ year and continues negatively. However, the response of GOEX is positive at the beginning until the $2^{\text {nd }}$ year, and then continues negatively. On the other hand, the response of MANU to REX, GOEX, and MINING is similar to the forgone analysis above with the exception of the response of MANU to OILPD, where it was positive at the beginning the turned to be negative till the end of the time span. Also, it should be noted that, with OILPI, ECT is negative and significant at 5 percent level and is about 245 percent. The error correcting term, explains the speed at which the system adjust to equilibrium at the rate of 245 percent annually. Nonetheless, with OILPD, ECT is negative and not significant and is about 72 percent. In sum, the results show the spectacular effects of the oil price changes on the Saudi economy. Thus, changes in earnings, changes in GOEX and REX influence MANU, and hence, influence the efforts of diversifications. 
Vol. 9, No. 4, pp. 217-229, August 2017

Table 6: Impulse response to Cholesky (d.f. adjusted) one S. D. innovations

Variance Decomposition for Oil Price Increase, OILPI

\begin{tabular}{llllll}
\hline Period & OILPI & GOEX & MINING & REX & MANU \\
\hline 1 & 20.75056 & 0.000000 & 0.000000 & 0.000000 & 0.000000 \\
5 & 1.038034 & -1.458611 & -1.301539 & 4.165382 & 1.343698 \\
10 & -0.472413 & 0.387826 & 0.073506 & -1.116644 & 0.222961 \\
15 & 0.021498 & 0.308906 & 0.089105 & -0.045964 & -0.127216 \\
25 & -0.022451 & 0.072786 & -0.007259 & 0.000654 & 0.036495
\end{tabular}

Variance Decomposition for GOEX

$\begin{array}{llllll}1 & -0.027133 & 0.184138 & 0.000000 & 0.000000 & 0.000000 \\ 5 & 0.009867 & -0.047373 & 0.040713 & 0.024979 & 0.028910 \\ 10 & -0.018175 & -0.015423 & 0.012441 & 0.021109 & 0.064858 \\ 15 & -0.009430 & -0.048726 & 0.023760 & 0.011823 & 0.050708 \\ 25 & -0.010652 & -0.016830 & 0.019720 & 0.010538 & 0.042543\end{array}$

Variance Decomposition for MINING

\begin{tabular}{|c|c|c|c|c|c|}
\hline 1 & 0.117732 & 0.020070 & 0.214468 & 0.000000 & 0.000000 \\
\hline 5 & -0.029086 & -0.118567 & 0.064733 & 0.082901 & 0.152435 \\
\hline 10 & -0.023944 & -0.070186 & 0.021152 & -0.015938 & 0.085641 \\
\hline 15 & -0.022806 & -0.032054 & 0.023406 & 0.012673 & 0.076699 \\
\hline 25 & -0.015970 & -0.025961 & 0.027375 & 0.016645 & 0.064989 \\
\hline \multicolumn{6}{|c|}{ Variance Decomposition for REX } \\
\hline 1 & -0.009924 & -0.002342 & -0.029375 & 0.036930 & 0.000000 \\
\hline 5 & 0.008237 & -0.006194 & 0.000554 & -0.011616 & -0.016374 \\
\hline 10 & 0.001356 & -0.001407 & -0.008385 & 0.003296 & -0.005328 \\
\hline 15 & 0.001430 & 0.003695 & -0.003740 & -0.005253 & -0.008786 \\
\hline 25 & 0.002319 & 0.004617 & -0.003591 & -0.001971 & -0.009326 \\
\hline \multicolumn{6}{|c|}{ Variance Decomposition for MANU } \\
\hline 1 & -0.005069 & 0.007836 & 0.031332 & -0.006856 & 0.035699 \\
\hline 5 & -0.010390 & -0.021087 & 0.029461 & 0.036327 & 0.062443 \\
\hline 10 & -0.015698 & -0.034508 & 0.030758 & 0.019380 & 0.070119 \\
\hline 15 & -0.016303 & -0.035165 & 0.026440 & 0.015867 & 0.067831 \\
\hline 25 & -0.015161 & -0.027501 & 0.025113 & 0.014155 & 0.061172 \\
\hline
\end{tabular}

Cholesky Ordering OILPI, GOEX, MINING, REX, and MANU 


\section{Journal of Economics and Behavioral Studies (ISSN: 2220-6140)}

Vol. 9, No. 4, pp. 217-229, August 2017

Table 7: Impulse response to Cholesky (d.f. adjusted) one S. D. innovations

\begin{tabular}{llllll}
\hline \multicolumn{5}{l}{ Variance Decomposition for Oil Price Increase, OILPD } \\
\hline Period & OILPD & GOEX & MINING & REX & MANU \\
\hline 1 & 15.32431 & 0.000000 & 0.000000 & 0.000000 & 0.000000 \\
5 & -0.814628 & -0.950783 & -0.641651 & 0.733851 & 0.255264 \\
10 & 0.101180 & -0.105525 & -0.177147 & -0.361415 & 0.086039 \\
15 & -0.009440 & 0.061103 & 0.010800 & 0.003709 & -0.002145 \\
25 & -0.005918 & -0.046618 & 0.036434 & -0.004864 & 0.045718 \\
Variance Decomposition for GOEX & & & \\
1 & -0.029586 & 0.212397 & 0.000000 & 0.000000 & 0.000000 \\
5 & -0.025052 & -0.026705 & 0.087965 & -0.012445 & 0.046553 \\
10 & -0.002602 & -0.073436 & 0.031089 & -0.005858 & 0.035891 \\
15 & -0.003728 & -0.037187 & 0.012234 & -0.004605 & 0.028299 \\
25 & -0.004184 & -0.021927 & 0.016886 & -0.001295 & 0.024623 \\
Variance Decomposition for MINING & & & \\
1 & 0.179023 & 0.032461 & 0.228870 & 0.000000 & 0.000000 \\
5 & -0.021056 & -0.147470 & 0.079893 & -0.009769 & 0.101895 \\
10 & 0.003766 & -0.089139 & 0.016729 & -0.035729 & 0.046107 \\
15 & -0.007164 & -0.035166 & 0.017495 & -0.002689 & 0.038018 \\
25 & -0.005792 & -0.033277 & 0.025117 & -0.002231 & 0.035646 \\
Variance Decomposition for REX & & & \\
1 & -0.025498 & -0.009330 & -0.019930 & 0.035961 & 0.000000 \\
5 & 0.008168 & -0.001810 & 0.005306 & -0.008723 & -0.015047 \\
10 & -0.000546 & 0.000469 & -0.004703 & 0.005169 & -0.006265 \\
15 & 0.001429 & 0.006374 & -0.006185 & -0.000856 & -0.006440 \\
25 & 0.000877 & 0.005982 & -0.003833 & 0.000655 & -0.005952 \\
Variance Decomposition for MANU & & & \\
1 & 0.013055 & 0.007663 & 0.016040 & -0.011755 & 0.036835 \\
5 & -0.012005 & -0.035502 & 0.048008 & 0.007907 & 0.049618 \\
10 & -0.006297 & -0.052684 & 0.033644 & -0.005243 & 0.046624 \\
15 & -0.006128 & -0.043862 & 0.026497 & -0.004555 & 0.041617 \\
25 & -0.005724 & -0.033954 & 0.023708 & -0.002676 & 0.035618 \\
\hline
\end{tabular}

Cholesky Ordering OILPD, GOEX, MINING, REX, and MANU

Figure 2: Responses of GOEX, REX, MINING, and MANU to an OILPI

\section{Response to cholesky Ohe S.D. IInovations}

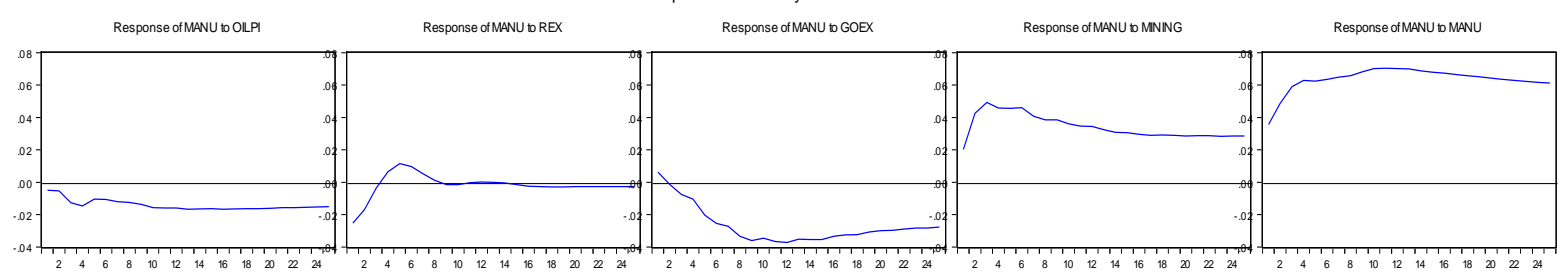


Figure 3: Responses of GOEX, REX, MINING, and MANU to an OILPD

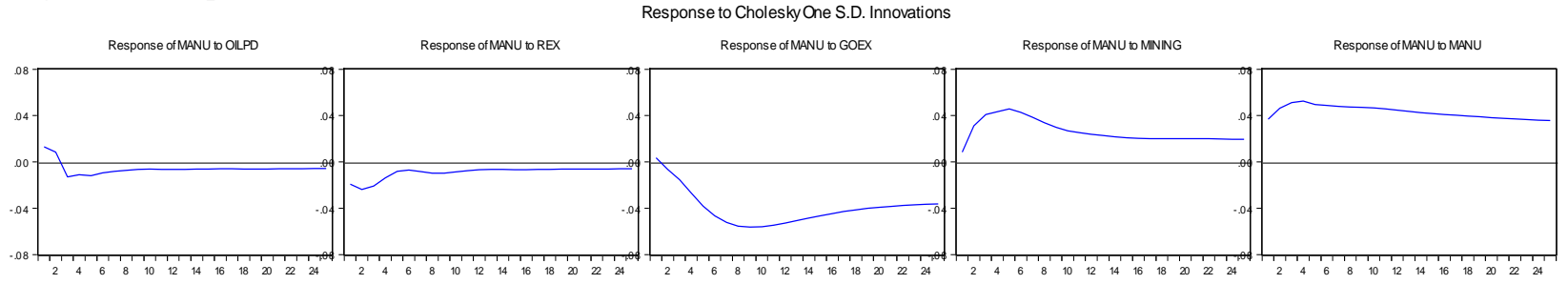

\section{Conclusion and Policy Recommendations}

The aim of this paper has been to analyze and investigate the effects of oil price fluctuations on the Saudi manufacturing (traded) sector. The recent variations of the oil prices in international oil market shed light on the ongoing efforts of diversifications of the economy. Hence, such study can help policy makers in deciding the directions of priorities. As a matter of fact, this paper has examined thoroughly the impacts of such a shock (increase and decrease) on the manufacturing sector for the period of 1975-2015. The non-linear oil price changes have been investigated using structural VAR (SVAR) model. The Johansen co-integration tests showed an existence of long-run relationships among the variables, a non-linear oil price shocks (OILPI and OILPD), GOEX, REX, MINING, and MANU. In the short-run, and based on equations (7 and 8), REX influenced the MANU negatively. Furthermore, a 10 percent change in REX will affect MANU by 21 percent. The coefficient is significant at 1 percent level and has the expected sign. On the other hand, the government's effort to diversify the Saudi economy is clear. A 10 percent increase in government spending (the spending effect) leads to an increase in MANU by 6 percent, and vice versa. The results here are in line with the findings in the Dutch disease literature, Kamas (1986), Javaid (2011), Lar et al. (2016), Mironov and Petronevich (2015), and Taguchi and Lama (2016). By and large, it is clear from analysis that fluctuations in oil prices and oil earnings reflect upon the macroeconomic variables. Planning to nullify the severe impacts of Dutch disease symptoms must go through a good balanced strategy in diversifying the production base. As has been noted, in the long-run, sustainable supporting programs for the traded goods have to be well financed and established. Frequent support programs create unstable supply of goods and services. Pressure on government to cure the deficit should not hinder the efforts of creating strong traded goods base. In brief, the rise in domestic prices will affect relative prices which in turn will strongly influence traded goods sector negatively. Given these points, fiscal policy should be coordinated with the central bank (SAMA) to maintain stable prices to keep the traded sector progressing.

\section{References}

Acosta, P., Lartey, E. \& Mandelman, F. (2007).Remittances and the Dutch Disease. Federal Reserve Bank of Atlanta Working Paper, 8, 1-38.

Algaeed, A. (2017). The Effects of Non-Linear Oil Price Shocks on the Saudi Saving-Investment Behavior. Journal of Economics and Financial Issues, 7(2), 155-165.

Botta, A. (2014). The Macroeconomics of Financial Dutch Disease. DEM Working Paper Series, 89, 09-14. Department of Economics and Management. Universits Mediterraneadi Reggo Calbria.

Corden, M. \& Neary, J. P. (1982). Booming Sector and De-in dustrialisation in a Small Open Economy. The Economic Journal, 92, 829-831.

Corden, M. (1984). Booming Sector and Dutch Disease Economics: Survey and Consolidation. Oxford Economic Papers, 36(3), 359-380.

Corden, M. (1986). Fiscal Policies, Current Accounts and Real Exchange Rates: In Search of a Logic of International Policy Coordination. Weltwirt. Arch, 122, 423-438.

Enders, K. \& Herberg, H. (1982). The Dutch Disease: Causes, Consequences and Calamities. Weltwirt. Arch, 83$84,473-497$.

Eromenko, I. (2016). Do Remittances Cause Dutch Disease in Resource Poor Countries of Central Asia? Central Asia Economic Papers, No. 18, January 2016.

Fardmanesh, M. (1991). Dutch Disease Economics and the Oil Syndrome: An Empirical Study. World Development, 19(6), 711-717. 
Fielding, D. \& Gibson, F. (2012). Aid and Dutch Disease in Sub-Saharan Africa. Journal of African Economies, 22(1), 1-21.

Gregory, R. (1976). Some Implications of the Growth of the Mineral Sector. Australian Journal of Agriculture Economics, 20, 71-91.

Hagen, E. (1968). Economic Growth with Unlimited Foreign Exchange and No Technical Progress, in Bhagwatti, J. N. and Eckaus, R. S. eds., Development and Planning.

Hamilton, J. D. (1996). This is What Happened to the Oil Price Macro economy Relationship. Journal of Monetary Economics, 38(2), 215-220.

Hjalmarsson, E. \& Osterhold, P. (2007). Testing for Co-integration Using the Johansen Methodology Where Variables are Near-Integrated. IMF Working Paper; WP/07/141.

Javaid, S. (2011). Dutch Disease Investigated: Empirical Evidence from Selected South-East Asian Economies. Journal of Economic Cooperation and Development, 34(4), 51-74.

Kamas, L. (1986). Dutch Disease Economics and the Colombian Export Boom. World Development, 4, 11771198.

Lee, K., Ni, S. \& Ratti, R. (1995). Oil Shocks and the Macro economy: The Role of Price Variability. The Energy Journal, 16(4), 39-56.

Lama, R. \& Medina, J. (2012). Is Exchange Rate Stabilization an Appropriate Cure for the Dutch Disease?. International Journal of Central Banking, 3, 5-42.

Lar, N., Taguchi, T. \& Sakurai, H. (2016). Does Foreign Aid Cause Dutch Disease: Case of Cambodia, Lao PDR, Myanmar, and Vietnam. Journal of Reviews on Global Economics, 5, 180-189.

Long, N. (1983). The Effects of a Booming Export Industry on the Rest of the Economy. The Economic Record, 58(59), 57-59.

Magud, N. \& Sosa, S. (2010). When and Why Worry about Real Exchange Rate Appreciation? The Missing Link between Dutch Disease and Growth. IMF Working Paper WP/10/271, 1-33.

Mironov, V. \& Petronevich, A. (2015).Discovering the Signs of Dutch Disease in Russia. Bank of Finland, BOFIT Discussion Papers 3/2015.

Mork, K. (1989). Oil Shocks and the Macro economy when Prices Go Up and Down: An Extension of Hamilton's Results. Journal of Political Economy, 97(4), 740-744.

Neary, P. \& Corden, M. (1982). Booming Sector and De-industrialization in a Small Open Economy. The Economic Journal, 92, 825-848.

Neary, P. \& Wijnbergen, S. (1984). Can Oil Discovery Lead to a Recession? A comment on Eastwood and Venables. The Economic Journal, 94, 390-395.

Paldam, M. (2013). The Political Economy of the Dutch Disease-A Survey. In Cabrillo, F., Puchades, ed. Constitutional Economics and Public Institutions. Essays in Honor of Jose-Pardo Edwards Elgar, Cheltentiam, U.K.

Porter, M. (1978). External Shocks and Stabilization Policy in a Small Open Economy: The Australian Experience. Weltwirt. Archive, 114, 709-735.

Rossi, E. (2004). Impulse Response Functions. Lecture Notes, Econometrics 10. Department of Economics, Universita di Pavia.

Rudd, D. (1996). An Empirical Analysis of Dutch Disease: Developing and Developed Countries. Economic Department, Honors Projects, Illinois Wesleyan University.

Snape, R. (1977). Effects of Mineral Development on the Economy. The Australian Journal of Agricultural Economics, 21, 147-156.

Taguchi, H. \& Lama, B. (2016). Do Emigrant's Remittances Cause Dutch Disease? The Case of Nepal and Bangladesh. Research in Applied Economics, 8(4), 1-14.

Trevino, J. (2011). Oil Price Boom and Real Exchange Rate Appreciation: Is there Dutch Disease in the CEMAC? IMF Working Paper WP/11/268, 1-30.

Wijnbergen, S. (1984). The Dutch Disease: A Disease after All. The Economic Journal, 94, 41-55.

Wijnbergen, S. (1984). Inflation, Employment, and Dutch Disease in Oil-Exporting Countries: A Short-run Disequilibrium Analysis. Quarterly Journal of Economics, 99, 233-250.

Zuzana, I. (2016). The Dutch Disease: An Overview. European Scientific Journal, Special Edition, August, 2016. 